\title{
Evaluation of the renoprotective effect of syringic acid against nephrotoxicity induced by cisplatin in rats
}

\author{
Hardevinder Pal Singh ${ }^{1,2}$, Thakur Gurjeet Singh ${ }^{1 *}$, Randhir Singh \\ 'Department of Pharmacy, Government Medical College Patiala, Patiala, India \\ ${ }^{2}$ Chitkara College of Pharmacy, Chitkara University, Punjab, India \\ ${ }^{3} \mathrm{MM}$ College of Pharmacy, Maharishi Markandeshwar University, Ambala, India.
}

\begin{tabular}{|c|}
\hline ARTICLE INFO \\
\hline $\begin{array}{l}\text { Received on: } 13 / 04 / 2020 \\
\text { Accepted on: } 13 / 08 / 2020 \\
\text { Available online: } 25 / 02 / 2021\end{array}$ \\
\hline $\begin{array}{l}\text { Key words: } \\
\text { Cisplatin, nephrotoxicity, } \\
\text { oxidative stress, syringic acid, } \\
\text { nitric oxide synthase. }\end{array}$ \\
\hline
\end{tabular}

\begin{abstract}
The present study investigated the role of syringic acid (SA) in the renal protection mediated through the nitric oxide synthase (NOS) pathway in rodents treated with cisplatin (CP) with a single nephrotoxic dose of $5 \mathrm{mg} / \mathrm{kg}$ (i.p.) on the day the study commenced. The nephrotoxicity caused by a single dose of $\mathrm{CP}$ was assessed by measuring renal functional test (in serum and urine), oxidative stress parameters, and histopathological evaluation with hematoxylin and eosin stain in renal tissue on day 5, i.e., the last day of the study. The Administration of SA provides significant ( $p$ $<0.05$ ) dose-mediated (50 and $100 \mathrm{mg} / \mathrm{kg}$, p.o.) nephroprotection in CP-treated male Wistar rats. Pretreatment with NOS inhibitor, L-nitroarginine methyl ester $(20 \mathrm{mg} / \mathrm{kg}$, i.p.) in rats abolished the nephroprotective prospective of SA. SA-mediated activation of the NOS pathway has been hypothesized to contribute to renoprotection.
\end{abstract}

\section{INTRODUCTION}

As per data available, drug-induced nephrotoxicity accounts for $19 \%-26 \%$ of cases in hospitalized patients but its occurrence rate drastically increases in patients undergoing chemotherapy, especially in case of cisplatin (CP) (Izzedine and Perazella, 2017). To treat the solid tumor, CP is one of the most successful chemotherapeutic agent, but nausea, vomiting, neurotoxicity, and ototoxicity hinder its use. Among all these side effects, nephrotoxicity is the major factor that must be considered before the use of CP. Nephrotoxicity affects nearly $28 \%-36 \%$ of the patients receiving therapeutic dose of CP (Alhoshani et al., 2017). Moreover, the chances of nephrotoxicity increase significantly along with patient age and co-morbidities (Liu et al., 2018). The accumulation of CP is found to be five times more in kidney as compared to blood (Peres and da Cunha, 2013). Several studies indicates that $\mathrm{CP}$ accumulation in kidneys results in production of reactive oxygen species (ROS), inflammation,

Abstract of this article was presented at CUDC consortium and Summer School Conference at Chitkara University, India.

*Corresponding Author

Thakur Gurjeet Singh, Chitkara College of Pharmacy, Chitkara

University, Rajpura,India.E-mail: gurjeet.singh@chitkara.edu.in increases lipid peroxidation, and reduces the level of antioxidant, mitochondrial dysfunction along with deoxyribonucleic acid (DNA) adduct formation and free radicals mediated apoptotic pathways activation (Jilanchi et al., 2018; Manohar and Leung, 2018; Sultana et al., 2012).

Natural antioxidants in recent years have created considerable interest as potential therapeutic agents in prevention of diseases progression. Natural compounds isolated from plant species were found to have anti-inflammatory, antioxidant, inhibition of lipid peroxidation, antimutagenic activity, and production of free radicals. Out of the natural compounds, phenolic acids which possess antioxidant and antiproliferative properties are considered as one of the potential groups of interest for pharmacological properties. Phenolic compounds are found in nuts, fruits, seeds, vegetables, and in all types of red wine and tea (Srinivasulu et al., 2018). Syringic acid (SA) is a natural active phenolic phytoconstituent 4-hydroxy-3, 5 dimethoxy benzoic acid isolated from honey, Radix isatidis, olive, grape, pomegranate, green tea, Isatis indigotica, and mushroom (Sancaktutar et al., 2014). SA exhibits useful properties, such as anti-microbial, anti-inflammatory, antiproliferative, antioxidative, antitumor, antidiabetic, and hepatoprotective (Kumar et al., 2012; Ramachandran and Raja 2010). SA scavenging radicals reduce 
production of malondialdehyde and ameliorate the pancreatitis induced by L-arginine in rats (Cikman et al., 2015).

Previous studies established that that nitric oxide synthase (NOS)-mediated double-edge sword nitric oxide (NO) plays an imperative role in the pathobiology of nephrotoxicity induced via $\mathrm{CP}$ treatment by modulating the oxidative stress in renal tissues (Gharibi et al., 2017; Singh et al., 2019).

One of three isoforms of NOS, i.e., inducible NOS (iNOS), is activated and enhances expression in renal tissues under degenerative and inflammatory conditions. The main physiological role of endothelial nitric oxide synthase (eNOS) is to control renal blood flow, glomerular filtration rate, and vascular tone in urinary system (Cherla and Jaimes, 2004). Furchgott and Zawadzki (1980) reported that NO is an endothelium-derived relaxing factor that controls the vascularity of renal smooth muscles and its proliferation and angiogenesis. NO prevents the accumulation of platelets by the repression of endothelium leucocyte adherence. Murohara et al. (1999) demonstrated that the inhibition of NOS by the L-NAME significantly prevents the proliferation and angiogenesis of endothelial cells.

On the basis of previous findings the present study was designed to explore the nephroprotective effect of SA in CP induced nephrotoxicity, as well as to investigate the mechanistic role of $\mathrm{NO}$ in SA-mediated attenuation of CP-induced nephrotoxicity in rats.

\section{MATERIAL AND METHODS}

The current study was approved by the Institutional Animal Ethical Committee under registration number: 1181/PO/ Ebi/08/Committee for the Purpose of Control And Supervision of Experiments on Animals (CPCSEA) and experimental protocol was approved by and carried out according to the instructions of the CPCSEA under the aegis of Ministry of Fisheries, Animal Husbandry and Dairying, Government of India,. In this study, we used inbred -male Wistar rats weighing 200-250 g. CP-induced nephrotoxicity is found to be a gender-related drug and variations in renal circulation in both genders may affect the outcomes of study. To overcome the possible variations, only male rats were included in present study (Nematbakhsh et al., 2013). The animals were kept in animal houses as per the standard procedure laid down by the CPCSEA.

On the final day of the study, animals were euthanized under anesthesia and kidneys were removed, and urine and blood samples were taken away for testing various parameters.

\section{Drugs and experimental models}

SA, CP, and other chemicals were obtained from SigmaAldrich Chemical Co. L-nitroarginine methyl ester (L-NAME) was dissolved in $0.9 \%$ saline. Animals were divided into five groups and each group comprised six male rats. Nephrotoxicity was induced intraperitoneally by a single dose of $\mathrm{CP}(5 \mathrm{mg} / \mathrm{kg}$ i.p. $)$ on the first day of the study. As per the previous literature and pilot study, we selected two dose levels of SA [50 and $100 \mathrm{mg} / \mathrm{kg}$ (p.o.)] to administer orally once a day in the morning for the remaining 4 days (Kumar et al., 2012; Ramachandran and Raja 2010). Male Wistar rats were sacrificed on fifth day after collecting the blood samples the by cervical dislocation under effect of anesthesia. The serum creatinine, blood urea nitrogen (BUN), serum magnesium, and serum potassium levels were estimated in blood samples.
The microprotein, sodium, and creatinine clearance were also determined from urine samples by placing the rats in metabolic cages individually. After animal scarification, a portion of kidney tissue was preserved after fixing with formalin for histopathological studies and a small part of kidney tissue was used for assessment of superoxide anion generation (SAG) (Singh et al., 2020).

The remaining of kidney tissue was used for the estimation of myeloperoxidase (MPO) activity, thiobarbituric acid reactive substances (TBARS), reduced glutathione (GSH) as per the procedure described by Kapil et al. (2013), Sehajpal et al. (2014), Singh et al. (2020). ELISA method was used for the estimation of tumor necrosis factor-alpha (TNF- $\alpha)$, interleukin-1 beta (IL-1 $\beta$ ), and nuclear factor kappa B (NF- $\kappa \mathrm{B}$ ) levels (Singh et al., 2020) and eNOS in renal tissue as per the procedure described by Czambel et al. (2010) along with the instruction of the company manual.

\section{Experimental protocol}

The animals in the study were divided into five groups, with six male Wistar rats in each group.

Group 1 (vehicle control): Saline as vehicle $(10 \mathrm{ml} / \mathrm{kg}$, i.p.) for $\mathrm{CP}$ and $\mathrm{SA}$ was administered to the male Wistar rats once daily for 5 days.

Group 2 (CP control): The nephrotoxicity was induced by the administration of a single nephrotoxic dose of CP of $5 \mathrm{mg} /$ $\mathrm{kg}$, (i.p.) to all the Wistar rats except group I on day 1 .

Group 3 \& 4 [SA (50 and $100 \mathrm{mg} / \mathrm{kg}$ (p.o.)] + CP (5 mg/ kg, i.p.) Group]: SA (50 and $100 \mathrm{mg} / \mathrm{kg} /$ day, p.o.) was administered to male Wistar rats of the respective groups 3 and 4 for 4 days, and the rest of the procedure as per group 2.

Group 5 [SA (100 mg/kg, p.o.) + L-NAME (20 mg/kg i.p.)]: The L-NAME (20 mg/kg i.p.) was administered 30 minutes before treatment of $100 \mathrm{mg} / \mathrm{kg} /$ days, p.o. SA to Wistar rats for consequent 4 days, and the rest of the procedure as per Group 2.

\section{Statistical analysis}

Statistical analysis was carried out on data collected from various treatment groups with the help of software Sigmastat 4.0 (Systat Software, San Jose, CA). One-way analysis of variance, followed by Tukey's multiple range tests was used to obtain the definitive results as expressed in mean \pm standard error of mean and $p<0.05$ was considered to be statistically significant.

\section{RESULTS AND DISCUSSION}

$\mathrm{CP}$ is a drug of choice to treat solid tumors, but its duration and dose-related nephrotoxicity lemmatizes it uses as a chemotherapeutic agent. CP's slow excretion rate and high accumulation in kidney as compared to blood is the main factor responsible for $\mathrm{CP}$-induced deleterious effects on kidney (Peres and da Cunha, 2013). CP-sinduced nephrotoxicity is illustrated by a decrease in renal function which leads to increase in blood urea and serum creatinine levels (Farooqui et al., 2017).

In the current study, blood urea, serum creatinine levels, serum magnesium, and serum potassium were found to be significantly elevated, whereas the creatinine clearance rate was significantly reduced in the $\mathrm{CP}$ group as compared to vehicle group. Treatment with SA (50 and $100 \mathrm{mg} / \mathrm{kg}$, p.o.) significantly increased the creatinine clearance rate, whereas elevated levels 
of BUN, uric acid, serum magnesium, and serum potassium were found to be attenuated significantly $(p<0.05)$, Moreover, the effect was found to be dose-dependent. The pretreatment with L-NAME (20 mg/kg i.p.) extensively abolished the renoprotection produced by SA (100 mg/kg) (Table 1). CP significantly elevated the level of $\mathrm{Fe}_{\mathrm{Na}}$ level in and microprotein urea level in urine as compared to vehicle control group, whereas the treatment with different dosages of SA (50 and $100 \mathrm{mg} / \mathrm{kg} \mathrm{p.o.)} \mathrm{attenuated} \mathrm{the} \mathrm{elevated} \mathrm{levels} \mathrm{of}$ $\mathrm{Fe}_{\mathrm{Na}}$ and microprotein urea, and the administration of L-NAME (20 $\mathrm{mg} / \mathrm{kg}$ i.p.) abolished the protection provided by the highest dose of SA (100 mg/kg p.o.) (Table 1). The renoprotective effect of SA against $\mathrm{CP}$ nephrotoxicity in present study can be characterized by the restoration of altered renal function and renal histology.

$\mathrm{CP}$-induced oxidative stress in renal tissue alters the structure and functioning of parenchymal cell that reduces the antioxidant mechanisms' results in the production of inflammatory mediators, causes histopathological changes, dysfunction, and apoptosis of renal tissue, and leads to nephrotoxicity (Abdel Moneim et al., 2014). CP-induced nephrotoxicity was also associated with altered level of MPO, TBARS, SAG, and GSH levels. Previous studies indicated the nephrotoxic effect of CPmediated through activation of ROS and free radical formation that directly enhances the oxidative stress in renal tissue (Kuhad et al., 2007; Singh et al., 2020). Similarly, in the current study MPO, TBARS, and SAG levels were found to be elevated, whereas antioxidant enzymes levels (GSH) were found to be reduced as compared to vehicle control animals. Treatment with SA (50 and $100 \mathrm{mg} / \mathrm{kg}$, p.o.) significantly attenuated the elevated level of MPO, TBARS, SAG, and increased the level of GSH (Table 2), whereas the administration of L-NAME abolished the antioxidant activity of SA. Nicorandil exerted its nephroprotective, anti-inflammatory, and antioxidative effects on rats suffering from ureteral obstruction by improving the NO production and enhancing the expression of eNOS in renal tissue (Ozturk et al., 2017).

In the current study, the SA (50 and $100 \mathrm{mg} / \mathrm{kg}$, p.o.) administration significantly $(p<0.05)$ and dose-dependently diminishes lipid peroxidation, inflammation, and increases the GSH level in the renal tissue (Table 2). These outcomes are in accordance with earlier study, which demonstrated that SA can shield the kidney from acetaminophen-induced nephrotoxicity by improving the level of antioxidant elements (Ramachandran and Raja, 2010).

There are reports on those affirming that inflammation imparts a vital role in $\mathrm{CP}$-induced renal damage and that anti-

Table 1. Effect of various pharmacological treatments on renal function parameters in rats (serum and urine).

\begin{tabular}{|c|c|c|c|c|c|}
\hline $\begin{array}{l}\text { Group } \\
\text { Parameter }\end{array}$ & Vehicle control & CP control (5 mg/kg, i.p.) & $\begin{array}{l}\text { CP control (5 mg/kg, i.p.) } \\
\quad+\mathrm{SA}(50 \mathrm{mg} / \mathrm{kg}, \text { p.o. })\end{array}$ & $\begin{array}{l}\text { CP control (5 mg/kg, i.p.) } \\
\text { + SA }(100 \mathrm{mg} / \mathrm{kg}, \text { p.o. })\end{array}$ & $\begin{array}{l}\text { CP control (5 mg/kg, i.p.) } \\
\text { + SA (100 mg/kg, p.o.) + } \\
\text { L-Name }(20 \mathrm{mg} / \mathrm{kg}, \text { i.p. })\end{array}$ \\
\hline $\begin{array}{l}\text { Serum creatinine } \\
(\mathrm{mg} / \mathrm{dl})\end{array}$ & $0.56 \pm 0.060$ & $2.78 \pm 0.614^{a}$ & $1.53 \pm 0.218^{\mathrm{b}}$ & $0.86 \pm 0.126^{b}$ & $2.48 \pm 0.317^{\mathrm{c}}$ \\
\hline $\mathrm{CrCl}(\mathrm{ml} / \mathrm{min} / \mathrm{Kg})$ & $1.28 \pm 0.045$ & $0.33 \pm 0.062^{\mathrm{a}}$ & $0.58 \pm 0.048^{b}$ & $0.93 \pm 0.042^{b}$ & $0.312 \pm 0.035^{c}$ \\
\hline Serum urea $(\mathrm{mg} / \mathrm{dL})$ & $31.97 \pm 5.206$ & $109.95 \pm 5.760^{\mathrm{a}}$ & $72.59 \pm 5.74^{b}$ & $54.26 \pm 4.51^{\mathrm{b}}$ & $98.12 \pm 6.24^{\mathrm{c}}$ \\
\hline $\begin{array}{l}\text { Serum potassium } \\
(\mathrm{mM} / \mathrm{L})\end{array}$ & $8.38 \pm 0.777$ & $4.28 \pm 0.361^{\mathrm{a}}$ & $5.72 \pm 0.361^{b}$ & $7.37 \pm 0.612^{b}$ & $3.82 \pm 0.364^{\mathrm{c}}$ \\
\hline $\begin{array}{l}\text { Serum magnesium } \\
(\mathrm{mEq} / \mathrm{L})\end{array}$ & $3.6 \pm 0.368$ & $1.53 \pm 0.165^{\mathrm{a}}$ & $1.97 \pm 0.216^{\mathrm{b}}$ & $2.58 \pm 0.303^{b}$ & $1.48 \pm 0.153^{\mathrm{c}}$ \\
\hline BUN & $22.2 \pm 3.574$ & $82.29 \pm 11.375^{\mathrm{a}}$ & $54.15 \pm 4.63^{b}$ & $32.91 \pm 3.27^{b}$ & $72.36 \pm 5.42^{\mathrm{c}}$ \\
\hline $\mathrm{FeNa}(\%)$ & $0.97 \pm 0.129$ & $6.35 \pm 0.784^{a}$ & $3.72 \pm 0.385^{b}$ & $1.87 \pm 0.292^{b}$ & $5.16 \pm 0.521^{\mathrm{c}}$ \\
\hline $\begin{array}{l}\text { Microproteinuria } \\
\text { (mg/day) }\end{array}$ & $4.33 \pm 0.307$ & $8.81 \pm 0.331^{\text {a }}$ & $6.19 \pm 0.396^{b}$ & $5.22 \pm 0.382^{b}$ & $8.35 \pm 0.526^{c}$ \\
\hline
\end{tabular}

Data are expressed as mean $\pm \operatorname{SEM}(n=6)$.

${ }^{\mathrm{a}} p<0.05$ versus vehicle control group.

${ }^{\mathrm{b}} p<0.05$ versus $\mathrm{CP}(5 \mathrm{mg} / \mathrm{kg}$, i.p. $)$.

${ }^{c} p<0.05$ versus $\mathrm{CP}(5 \mathrm{mg} / \mathrm{kg}$, i.p. $)+\mathrm{SA}(100 \mathrm{mg} / \mathrm{kg}$, p.o. $)$.

Table 2. Effect of various pharmacological treatments on oxidative stress parameters in rats.

\begin{tabular}{|c|c|c|c|c|c|}
\hline $\begin{array}{l}\text { Group } \\
\text { Parameter }\end{array}$ & Vehicle control & $\begin{array}{l}\text { CP control (5 mg/ } \\
\text { kg, i.p.) }\end{array}$ & $\begin{array}{l}\text { CP control (5 mg/kg, i.p.) + } \\
\text { SA (50 mg/kg, p.o.) }\end{array}$ & $\begin{array}{c}\text { CP control (5 mg/kg, } \\
\text { i.p. })+ \text { SA (100 mg/kg, } \\
\text { p.o. })\end{array}$ & $\begin{array}{c}\text { CP control (5 mg/kg, i.p. })+ \text { SA } \\
(100 \mathrm{mg} / \mathrm{kg}, \mathrm{p.o.})+\text { Name }(20 \\
\text { mg/kg, i.p. })\end{array}$ \\
\hline $\begin{array}{l}\text { TBARS }(\mu \mathrm{M} / \mathrm{mg} \text { of } \\
\text { Protein) }\end{array}$ & $0.45 \pm 0.052$ & $1.55 \pm 0.085^{\mathrm{a}}$ & $0.98 \pm 0.074^{\mathrm{b}}$ & $0.62 \pm 0.066^{\mathrm{b}}$ & $1.46 \pm 0.082^{\mathrm{c}}$ \\
\hline $\begin{array}{l}\mathrm{GSH}(\mathrm{mM} / \mathrm{mg} \text { of } \\
\text { protein) }\end{array}$ & $16.2 \pm 0.419$ & $5.35 \pm 0.84^{\mathrm{a}}$ & $10.13 \pm 0.6251^{b}$ & $15.91 \pm 0.53^{b}$ & $5.13 \pm 0.64^{c}$ \\
\hline $\begin{array}{l}\text { MPO (U/g of Renal } \\
\text { Tissue) }\end{array}$ & $1.79 \pm 0.520$ & $6.91 \pm 0.908^{\mathrm{a}}$ & $4.02 \pm 1.126^{\mathrm{b}}$ & $2.16 \pm 0.893 b$ & $6.39 \pm 2.859^{c}$ \\
\hline $\begin{array}{l}\text { SAG }(\mu \mathrm{M} / \mathrm{mg} \text { of } \\
\text { Protein })\end{array}$ & $21.4 \pm 0.647$ & $65.2 \pm 1.398^{\mathrm{a}}$ & $43.42 \pm 3.627^{b}$ & $29.54 \pm 3.41^{b}$ & $62.48 \pm 4.958^{\mathrm{c}}$ \\
\hline
\end{tabular}

Data are expressed as mean $\pm \operatorname{SEM}(n=6)$.

${ }^{\mathrm{a}} p<0.05$ versus vehicle control group.

${ }^{\mathrm{b}} p<0.05$ versus $\mathrm{CP}(5 \mathrm{mg} / \mathrm{kg}$, i.p. $)$.

${ }^{c} p<0.05$ versus $\mathrm{CP}(5 \mathrm{mg} / \mathrm{kg}$, i.p. $)+\mathrm{SA}(100 \mathrm{mg} / \mathrm{kg}$, p.o. $)$. 
inflammatory and antioxidant agents have been proven to reduce renal injuries (Kilic et al., 2017). In CP-treated animals, the levels of inflammatory chemokine and cytokines are elevated in renal tubular epithelium (Faubel et al., 2017). TNF- $\alpha$ and IL-1 $\beta$ among the other inflammatory cytokines plays a major role to initiate CP-induced inflammatory responses (Kuhad et al., 2007; Ramesh and Reeves, 2012; Singh and Singh, 2020). In inflamed renal parenchyma the IL- $1 \beta$ promotes the influx of circulating monocytes and TNF- $\alpha$ enhance the level of leucocytes by promoting the expression of adhesion molecules on renal endothelial cells (Kumar et al., 2012). Noori and Mahboob (2010) demonstrated that reduced eNOS and increased iNOS levels can enhance the peroxynitrite formation, neutrophilic mobility, inflammation, and tubular cell injury that leads to epithelial damage. Arab et al. (2018) also reported that ROS and proinflammatory cytokines are major triggers for apoptosis, inhibition of ROS, and proinflammatory cytokines by activating Akt/eNOS pathway can contribute to the abrogation of renal tubular apoptosis. Shahzad et al. (2019) reported that administration of SA was found to reduce the cytokine levels (i.e., TNF- $\alpha$ and IL-1 $\beta$ ), a marker for leukocytes/macrophage infiltration. In present study, wellestablished anti-inflammatory and antioxidative agent SA (50 and $100 \mathrm{mg} / \mathrm{kg}$, p.o.) significantly downregulated TNF- $\alpha$ and IL-1 $\beta$ levels in rats, thereby preventing inflammatory infiltration and apoptosis of renal tubules (Figs. 1 and 2). Xie et al. (1994), reported that NF- $\kappa \mathrm{B}$ plays a critical role in induction of iNOS. Pyrrolidine dithiocarbamate an antioxidant and selective inhibitor of NF-kB, blocked NO release, and decreased the expression of iNOS messenger RNA in lipopolysaccharides-stimulated mouse macrophages. Zhang (2004) reported that NF- $\mathrm{BB}$ inhibitor reverses hyperhomocysteinemia-induced renal damage in rats and decreases the iNOS expression in the renal tissue.

In underline study NF- $\kappa \mathrm{B}$ level was found to be significantly $(p<0.05)$ elevated in the $\mathrm{CP}$ group in comparison to vehicle control group indicating induction of inflammation. Administration of different dosages of SA $(50$ and $100 \mathrm{mg} / \mathrm{kg}$, p.o.) significantly $(p<0.05)$ and dose-dependently attenuated the elevated NF- $\kappa \mathrm{B}$ levels as compared to $\mathrm{CP}$ control group,



Figure 1. Effect of various treatments on level of TNF- $\alpha$ (pg/mg) in Renal Tissue. Data are expressed as mean \pm SEM. $(n=6)$

${ }^{\mathrm{a}} p<0.05$ Versus Vehicle control Group;

${ }^{\mathrm{b}} p<0.05$ Versus Cisplatin $(5 \mathrm{mg} / \mathrm{kg}$, i.p. $)$;

${ }^{c} p<0.05$ Versus Cisplatin ( $5 \mathrm{mg} / \mathrm{kg}$, i.p.) + Syringic acid ( $100 \mathrm{mg} / \mathrm{kg}$, p.o.) whereas administration of L-NAME (20 mg/kg i.p.) abolished the protection provided by SA (100 mg/kg p.o.) (Fig. 3).

Hopkins et al. (2003) stated that increased NO production by elevated iNOS expression plays a significant role in lung inflammation. Singh et al. (2019) reported that NOS-induced production of NO plays a critical role in the estradiol-mediated renoprotection in acute kidney injury, while previous treatment with L-NAME diminished the anti-apoptotic and anti-necrotic effect of estradiol. Kumar et al. (2012) reported that SA protects the kidney from adverse effects and preserve its functional capacity in L-NAME-induced hypertensive rats. Our findings showed that $\mathrm{CP}$ treatment decreased the eNOS levels of renal tissues. The levels of renal tissue eNOS were significantly $(p<0.05)$ and dosedependently modulated by SA (50 and $100 \mathrm{mg} / \mathrm{kg}$, p.o). This SAinduced protection was abolished by pretreatment of L-NAME (20 mg/kg i.p.) (Fig. 4). It is already established that intracellular messenger NO reacts with ROS and plays a key role in several pathological conditions. The increase in tissue NO level by reacting with superoxide anions leads to production of lipid peroxidation,

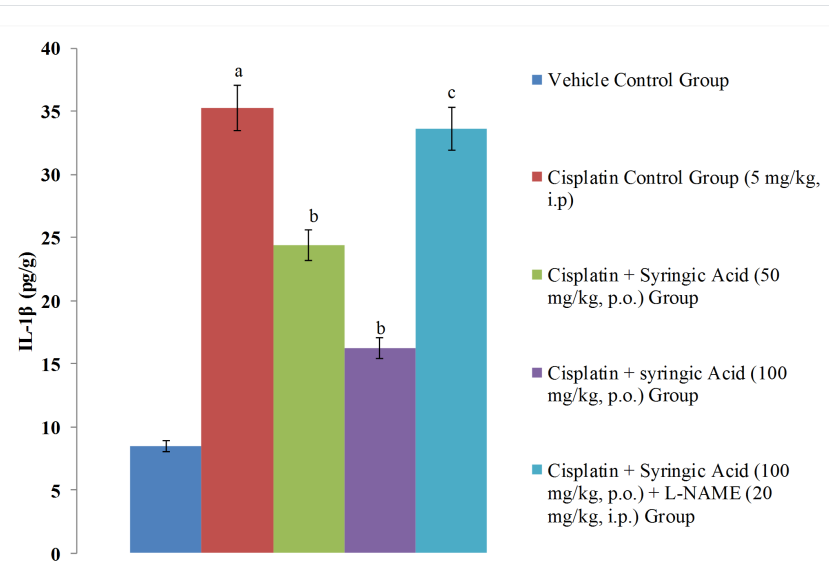

Figure 2. Effect of various treatments on level of IL-1 $\beta(\mathrm{pg} / \mathrm{g})$ in renal Tissue Data are expressed as mean \pm SEM. $(n=6)$ ${ }^{\mathrm{a}} p<0.05$ Versus Vehicle control Group; ${ }^{\mathrm{b}} \mathrm{p}<0.05$ Versus Cisplatin $(5 \mathrm{mg} / \mathrm{kg}$, i.p.); ${ }^{c} p<0.05$ Versus Cisplatin ( $5 \mathrm{mg} / \mathrm{kg}$, i.p.) + Syringic acid (100 mg/kg, p.o.).

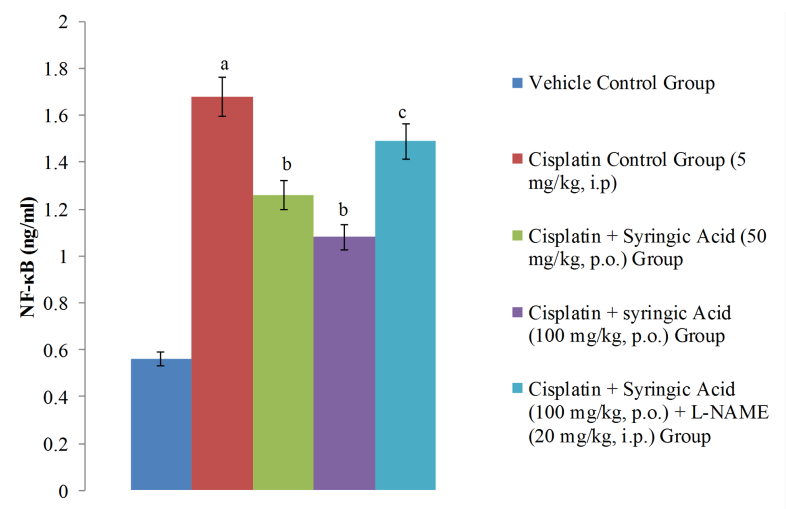

Figure 3. Effect of various treatments on level of NF- $\mathrm{BB}(\mathrm{ng} / \mathrm{ml})$ in renal Tissue. Data are expressed as mean \pm SEM. $(n=6)$ ${ }^{\mathrm{a}} p<0.05$ Versus Vehicle control Group; ${ }^{\mathrm{b}} p<0.05$ Versus Cisplatin $(5 \mathrm{mg} / \mathrm{kg}$, i.p.); ${ }^{\mathrm{c}} p<0.05$ Versus Cisplatin (5 mg/kg, i.p.) + Syringic acid (100 mg/kg, p.o.). 


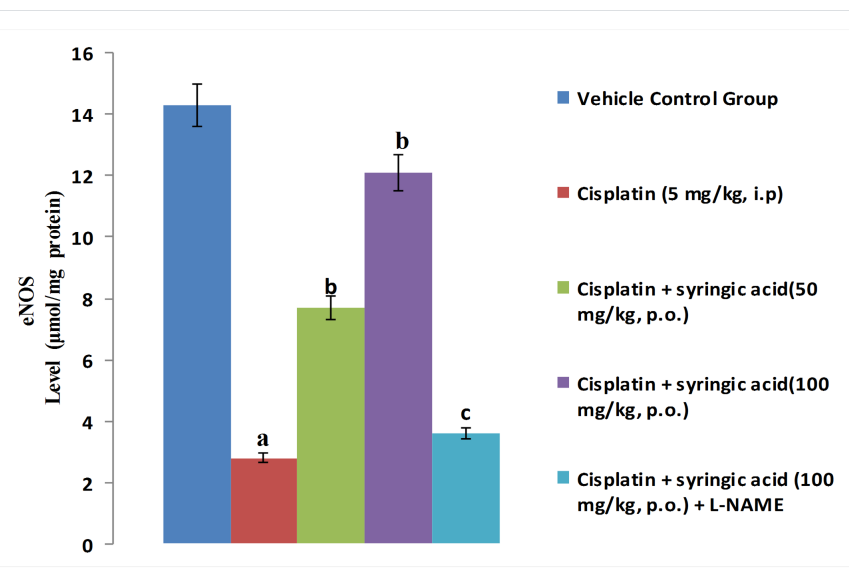

Figure 4. Effect of various treatments on eNOS level in renal tissue.

Data are expressed as mean \pm SEM. $(n=6)$

${ }^{\mathrm{a}} p<0.05$ Versus Vehicle control Group;

${ }^{\mathrm{b}} p<0.05$ Versus Cisplatin $(5 \mathrm{mg} / \mathrm{kg}$, i.p.);

${ }^{c} p<0.05$ Versus Cisplatin ( $5 \mathrm{mg} / \mathrm{kg}$, i.p.) + Syringic acid (100 mg/kg, p.o.).

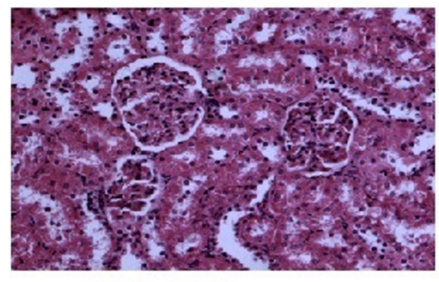

Vehicle Control

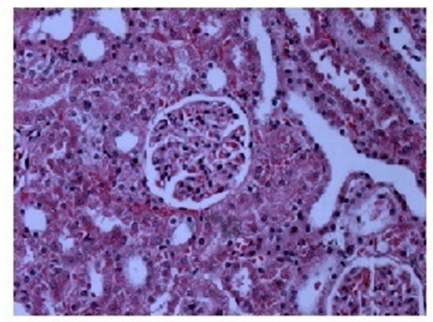

Cisplatin control (5 mg/kg, i.p.)+Syringic Acid (100 mg/kg, p.o.)

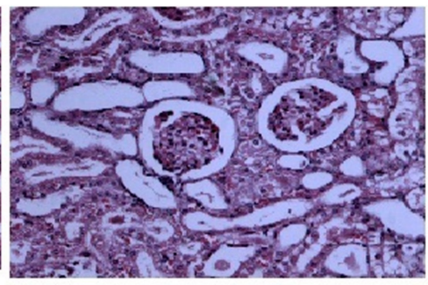

Cisplatin control $(5 \mathrm{mg} / \mathrm{kg}$, i.p.)

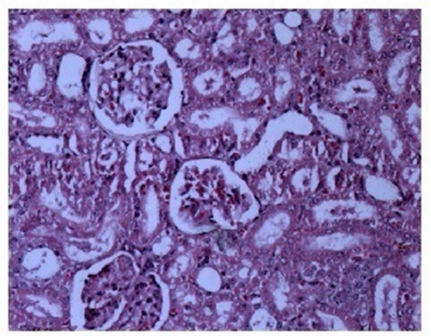

L Name $(20 \mathrm{mg} / \mathrm{kg}, \mathrm{i} . \mathrm{p})+$ Cisplatin control $(5$ $\mathrm{mg} / \mathrm{kg}$, i.p.)+Syringic Acid (100 mg/kg, p.o.)
Figure 5. The hematoxylin-eosin staining of renal sections at $200 \times$ magnification. (A) Vehicle Control, (B) Cisplatin control (5 mg/kg i.p.), (C) Cisplatin $(5 \mathrm{mg} /$ kg, i.p.) + Syringic Acid (50 mg/kg, p.o.), (D) Syringic Acid (100 mg/kg, p.o.), (E) Cisplatin (5 mg/kg, i.p.) + Syringic Acid (100 mg/kg, p.o.) + L-NAME (20 $\mathrm{mg} / \mathrm{kg}$, i.p.).

damages the DNA, and causes cell death (Kandhare et al., 2012). On the basis of above studies, it may be determined that SA decreases the expression of iNOS in renal tissue by inhibiting the inflammatory mediators. Histopathological examination has shown that SA (50 and $100 \mathrm{mg} / \mathrm{kg}$ p.o.) treatment decreased the neutrophil infiltration in parenchymal tissue, decreases the glomerular atrophy, and restores the texture of in renal tissue, whereas previous treatment with L-NAME reduces the anti-oxidative and anti-necrotic effect of SA and altered the renal histology of the rats treated with SA. We can summaries that the SA can produce a nephroprotective effect by abolishing renal dysfunctioning, oxidative stress, and increased free radicals produced by CP (Fig. 5).
In conclusion, SA therapy can produce a renoprotective effect in the nephrotoxicity produced by $\mathrm{CP}$ treatment. In addition, the SA-mediated regulation of specific forms of $\mathrm{NO}$ levels in the kidney imparts a significant function in the defense against nephrotoxicity caused by CP. The deleterious effects of chemotherapy on cancer patients will be reversed by SA treatment in the future. More mechanistic studies based on microarray and genomic models are required to validate the role of natural antioxidants in chemotherapy of the cancer patients.

\section{ACKNOWLEDGMENTS}

The authors are grateful to the Chitkara College of Pharmacy, Chitkara University, Rajpura, Patiala, Punjab, India, for providing the necessary facilities to carry out the research work.

\section{AUTHOR CONTRIBUTIONS}

All authors made substantial contributions to conception and design, acquisition of data, or analysis and interpretation of data; took part in drafting the article or revising it critically for important intellectual content; agreed to submit to the current journal; gave final approval of the version to be published; and agree to be accountable for all aspects of the work. All the authors are eligible to be an author as per the international committee of medical journal editors (ICMJE) requirements/guidelines.

\section{FUNDING}

There is no funding to report.

\section{CONFLICTS OF INTEREST}

The authors report no financial or any other conflicts of interest in this work.

\section{PUBLISHER'S NOTE}

This journal remains neutral with regard to jurisdictional claims in published institutional affiliation.

\section{REFERENCES}

Abdel Moneim AE, Othman MS, Aref AM. Azadirachta indica attenuates cisplatin-induced nephrotoxicity and oxidative stress. Biomed Res Int, 2014; 2014:647131.

Alhoshani AR, Hafez MM, Husain S, Al-Sheikh AM, Alotaibi MR, Al Rejaie SS, Alshammari MA, Almutairi MM, Al-Shabanah OA. Protective effect of rutin supplementation against cisplatin-induced nephrotoxicity in rats. BMC Nephrol, 2017; 18(1):194.

Arab HH, Salama SA, Maghrabi IA. Camel milk ameliorates 5-Fluorouracil-induced renal injury in rats: targeting MAPKs, NF- $\mathrm{KB}$ and PI3K/Akt/eNOS pathways. Cell Physiol Biochem, 2018; 46(4):1628-42.

Cherla G, Jaimes EA. Role of L-arginine in the pathogenesis and treatment of renal disease. J Nutr, 2004; 134(10 Suppl):2801S-6S.

Cikman O, Soylemez O, Ozkan OF, Kiraz HA, Sayar I, Ademoglu S, Taysi S, Karaayvaz M. Antioxidant activity of syringic acid prevents oxidative stress in 1-arginine-induced acute pancreatitis: an experimental study on rats. Int Surg, 2015; 100(5):891-6.

Czambel RK, Kharlamov A, Jones SC. Variations of brain endothelial nitric oxide synthase concentration in rat and mouse cortex. Nitric Oxide, 2010; 22(1):51-7.

Farooqui Z, Ahmed F, Rizwan S, Shahid F, Khan AA, Khan F. Protective effect of nigella sativa oil on cisplatin induced nephrotoxicity and oxidative damage in rat kidney. Biomed Pharmacother, 2017; 85:7-15.

Faubel S, Lewis EC, Reznikov L, Ljubanovic D, Hoke TS, Somerset H, Oh DJ, Lu L, Klein CL, Dinarello CA, Edelstein CL. Cisplatininduced acute renal failure is associated with an increase in the cytokines 
interleukin(IL)-1beta, IL-18, IL-6, and neutrophil infiltration in the kidney. J Pharmacol Exp Ther. 2007; 322(1):8-15.

Furchgott RF, Zawadzki JV. The obligatory role of endothelial cells in the relaxation of arterial smooth muscle by acetylcholine. Nature, 1980; 288(5789):373-6.

Gharibi F, Soltani N, Maleki M, Talebi A, Nasiri M, Shirdavani S, Nematbakhsh M. The protective effect of 1-arginine in cisplatin-induced nephrotoxicity in streptozotocin-induced diabetic rats. Adv Biomed Res, 2017; 6:100.

Hopkins N, Cadogan E, Giles S, Bannigan J, McLoughlin P. Type 2 nitric oxide synthase and protein nitration in chronic lung infection. J Pathol, 2003; 199(1):122-9.

Izzedine $\mathrm{H}$, Perazella MA. Anticancer drug-induced acute kidney injury. Kidney Int Rep, 2017; 2(4):504-14.

Jilanchi S, Talebi A, Nematbakhsh M. Cispaltin alters sodium excertion and renal clearance in rats: gender and drug dose related. Adv Biomed Res, 2018; 7:54

Kandhare AD, Raygude KS, Ghosh P, Ghule AE, Bodhankar SL. Neuroprotective effect of naringin by modulation of endogenous biomarkers in streptozotocin induced painful diabetic neuropathy. Fitoterapia, 2012; 83(4):650-9.

Kapil A, Singh JP, Kaur T, Singh B, Singh AP. Involvement of peroxisome proliferator-activated receptor gamma in vitamin-D mediated protection against acute kidney injury in rats. J Surg Res, 2013; 185(2): $774-83$.

Kilic U, Kilic E, Tuzcu Z, Tuzcu M, Ozercan IH, Yilmaz O, Sahin F, Sahin K. Melatonin suppresses cisplatin-induced nephrotoxicity via activation of Nrf-2/HO-1 pathway. Nutr Metab (Lond). 2013; 10(1):7.

Kuhad A, Pilkhwal S, Sharma S, Tirkey N, Chopra K. Effect of curcumin on inflammation and oxidative stress in cisplatin-induced experimentalnephrotoxicity. J Agric Food Chem, 2007; 55(25):10150-5.

Kumar S, Prahalathan P, Raja B. Syringic acid ameliorates (L)-NAME-induced hypertension by reducing oxidative stress. Naunyn Schmiedebergs Arch Pharmacol, 2012; 385(12):1175-84.

Liu JQ, Cai GY, Wang SY, Song YH, Xia YY, Liang S, Wang W, Nie S, Feng Z, Chen X. The characteristics and risk factors for cisplatininduced acute kidney injury in the elderly. Ther Clin Risk Manag, 2018; 14:1279-85.

Manohar S, Leung N. Cisplatin nephrotoxicity: a review of the literature. J Nephrol, 2018; 31(1):15-25.

Murohara T, Witzenbichler B, Spyridopoulos I, Asahara T, Ding B, Sullivan A, Losordo DW, Isner JM. Role of endothelial nitric oxide synthase in endothelial cell migration. Arterioscler Thromb Vasc Biol, 1999; 19(5):1156-61.

Nematbakhsh M, Ebrahimian S, Tooyserkani M, Eshraghi-Jazi F, Talebi A, Ashrafi F. Gender difference in cisplatin-induced nephrotoxicity in a rat model: greater intensity of damage in male than female. Nephrourol Mon, 2013; 5(3):818-21.

Noori S, Mahboob T. Antioxidant effect of carnosine pretreatment on cisplatin-induced renal oxidative stress in rats. Indian J Clin Biochem, 2010; 25(1):86-91.

Ozturk H, Firat T, Tekce BK, Yilmaz F. Effects of nicorandil on renal function and histopathology in rats with partial unilateral ureteral obstruction. Kaohsiung J Med Sci, 2017;33:236-45.
Peres LA, da Cunha AD Jr. Acute nephrotoxicity of cisplatin: molecular mechanisms. J Bras Nefrol, 2013; 35(4):332-40.

Ramachandran V, Raja B. Protective effects of syringic acid against acetaminophen induced hepatic damage in albino rats. J Basic Clin Physiol Pharmacol, 2010; 21(4):369-85.

Ramesh G, Reeves WB. TNF- $\alpha$ mediates chemokine and cytokine expression and renal injury in cisplatin nephrotoxicity. J Clin Invest. 2002; 110(6):835-42.

Sancaktutar AA, Bodakci MN, Hatipoglu NK, Soylemez H, Basar1l K, Turkcu G. The protective effects of pomegranate extracts against renal ischemia-reperfusion injury in malerats. Urol Ann, 2014; 6(1):46-50.

Sehajpal J, Kaur T, Bhatti R, Singh AP. Role of progesterone in melatonin-mediated protection against acute kidney injury. J Surg Res, 2014; 191(2):441-7.

Shahzad S, Mateen S, Naeem SS, Akhtar K, Rizvi W, Moin S. Syringic acid protects from isoproterenol induced cardiotoxicity in rats. Eur J Pharmacol, 2019; 849:135-45.

Singh S, Singh TG. Role of nuclear factor kappa B (NF-kB) signalling in neurodegenerative diseases: an mechanistic approach. Curr Neuropharmacol. 2020; 18(10):918-35.

Singh AP, Singh N, Pathak D, Bedi PMS. Estradiol attenuates ischemia reperfusion-induced acute kidney injury through PPAR- $\gamma$ stimulated eNOS activation in rats. Mol Cell Biochem. 2019; 453(1-2):1-9.

Singh HP, Singh TG, Singh R. Sinapic acid attenuates cisplatininduced nephrotoxicity through peroxisome proliferator-activated receptor gamma agonism in rats. J Pharm Bioallied Sci. 2020; 12(2):146-54.

Singh TG, Singh HP, Kaur S, Dhiman S. Protective effects of sesamol against cisplatin-induced nephrotoxicity in rats: a mechanistic approach. Obes Med, 2020; 19:100269.

Srinivasulu C, Ramgopal M, Ramanjaneyulu G, Anuradha CM, Suresh Kumar C. Syringic acid (SA) - A review of its occurrence, biosynthesis, pharmacological and industrial importance. Biomed Pharmacother, 2018; 108:547-57.

Sultana S, Verma K, Khan R. Nephroprotective efficacy of chrysin against cisplatin-induced toxicity via attenuation of oxidative stress. J Pharm Pharmacol, 2012; 64(6):872-81.

Xie QW, Kashiwabara Y, Nathan C. Role of transcription factor NF-kappa B/Rel in induction of nitric oxide synthase. J Biol Chem, 1994; 269(7):4705-8

Zhang F, Siow YL, Karmin O. Hyperhomocysteinemia activates NF- $\mathrm{kB}$ and inducible nitric oxide synthase in the kidney. Kidney Int, 2004; 65(4):1327-38

\section{How to cite this article:}

Singh HP, Singh TG, Singh R. Evaluation of the renoprotective effect of syringic acid against nephrotoxicity induced by cisplatin in rats. J Appl Pharm Sci, 2021; 11 (Supp 1):080-085. 